Check for updates

Cite this: RSC Adv., 2019, 9, 14586

Accepted 29th April 2019

DOI: $10.1039 / c 9 r a 01489 f$

rsc.li/rsc-advances

\section{Single crystal growth and structure analysis of type-I (Na/Sr)-(Ga/Si) quaternary clathrates $\uparrow$}

\author{
Hironao Urushiyama, ${ }^{\text {ab }}$ Haruhiko Morito (D) ${ }^{* c}$ and Hisanori Yamane (D) ${ }^{a}$ \\ Single crystals of $(\mathrm{Na} / \mathrm{Sr})-(\mathrm{Ga} / \mathrm{Si})$ quaternary type-I clathrates, $\mathrm{Na}_{8-y} \mathrm{Sr}_{y} \mathrm{Ga}_{x} \mathrm{Si}_{46-x}$, were synthesized by \\ evaporating $\mathrm{Na}$ from a mixture of $\mathrm{Na}-\mathrm{Sr}-\mathrm{Ga}-\mathrm{Si}-\mathrm{Sn}$ in a $6: 0.5: 1: 2: 1$ molar ratio at $773 \mathrm{~K}$ for $12 \mathrm{~h}$ in \\ an $\mathrm{Ar}$ atmosphere. Electron-probe microanalysis and single-crystal $\mathrm{X}$-ray diffraction revealed that three \\ crystals from the same product were $\mathrm{Na}_{8-y} \mathrm{Sr}_{y} \mathrm{Ga}_{x} \mathrm{Si}_{46-x}$ with $x$ and $y$ values of $7.6,2.96 ; 8.4,3.80$; and \\ 9.1, 4.08. It was also shown that increasing the $\mathrm{Sr}$ and $\mathrm{Ga}$ contents increased the electrical resistivity of \\ the crystal from 0.34 to $1.05 \mathrm{~m} \Omega \mathrm{cm}$ at $300 \mathrm{~K}$.
}

\section{Introduction}

Silicon (Si) clathrate compounds are composed of host $\mathrm{Si}$ atoms organized in three-dimensional frameworks and guest atoms enclosed in the Si cages of the frameworks. Kasper et al. first synthesized binary Si clathrate, $\mathrm{Na}_{8} \mathrm{Si}_{46}$, in $1965 .{ }^{1}$ Since then, many researchers have studied Si clathrate compounds, ${ }^{2}$ altering their physical properties by partial or full substitution of different elements for the host and guest atoms. Kawaji et al. synthesized a type-I clathrate, $(\mathrm{Na}, \mathrm{Ba})_{8} \mathrm{Si}_{46} ;{ }^{3}$ this compound was the first $\mathrm{Si}$ clathrate superconductor with a $T_{\mathrm{C}}$ value of $4 \mathrm{~K}$ derived from the partial substitution of $\mathrm{Ba}$ for $\mathrm{Na}$ in the $\mathrm{Na}_{8} \mathrm{Si}_{46}$ cages. Another $\mathrm{Si}$ clathrate, $\mathrm{Ba}_{8} \mathrm{Si}_{46}$, which was synthesized at high pressure ( $3 \mathrm{GPa}$ ) and $1073 \mathrm{~K}$, exhibited the highest $T_{\mathrm{C}}$ value $8 \mathrm{~K}$ among the various Si clathrate compounds. ${ }^{4}$ The framework $\mathrm{Si}$ atoms can also be partially replaced by $\mathrm{Ga}$ atoms in some type-I clathrate compounds, such as $\mathrm{A}_{8} \mathrm{Ga}_{8} \mathrm{Si}_{38}(\mathrm{~A}=\mathrm{K}, \mathrm{Rb}, \mathrm{Cs})$, as described by Sui et al. ${ }^{5} \mathrm{~A}_{8} \mathrm{Ga}_{8} \mathrm{Si}_{38}$ powder was sintered by spark plasma sintering to obtain bulk polycrystalline samples, which exhibited band gaps in the range of 1.14-1.18 eV. ${ }^{5}$ Another clathrate composed of $\mathrm{Ga} / \mathrm{Si}$ cages and $\mathrm{Ba}$ atoms, $\mathrm{Ba}_{7.94} \mathrm{Ga}_{15.33} \mathrm{Si}_{30.67}$, was shown to have a relatively high thermoelectric dimensionless figure of merit, $Z T$, of 0.87 at $870 \mathrm{~K} .^{6,7}$ $\mathrm{Sr}_{8} \mathrm{Ga}_{11} \mathrm{Si}_{35}{ }^{8}$ and $\mathrm{Sr}_{8} \mathrm{Ga}_{13.6} \mathrm{Si}_{32.4},{ }^{9}$ which contain $\mathrm{Sr}$ guest atoms in $\mathrm{Ga} / \mathrm{Si}$ cages, exhibit electrical resistivities of approximately 0.2 and $0.26 \mathrm{~m} \Omega \mathrm{cm}$, respectively, at $280 \mathrm{~K}$.

'Institute of Multidisciplinary Research for Advanced Materials, Tohoku University, 2-1-1 Katahira, Aoba-ku, Sendai 980-8577, Japan

${ }^{b}$ Department of Metallurgy, Materials Science and Materials Processing, Graduate School of Engineering, Tohoku University, 6-6-04 Aramaki Aza Aoba, Aoba-ku, Sendai 980-8579, Japan

'Institute for Materials Research, Tohoku University, 2-1-1 Katahira, Aoba-ku, Sendai 980-8577, Japan. E-mail: morito@imr.tohoku.ac.jp

$\dagger$ Electronic supplementary information (ESI) available. CCDC 1898606-1898608. For ESI and crystallographic data in CIF or other electronic format see DOI: 10.1039/c9ra01489f
Some ternary silicon clathrates could be synthesized via solidstate reactions between each elements at high temperature ${ }^{5}$ or melting method. ${ }^{6,8}, 9$ However, the silicon clathrates containing a Na atom could not be synthesized by simple reaction because these clathrates have been regarded as metastable or intermediate phases. These clathrates were generally prepared by thermal decomposition of the precursor compounds. For example, the binary silicon clathrates containing $\mathrm{Na}, \mathrm{Na}_{8} \mathrm{Si}_{46}$ and $\mathrm{Na}_{24} \mathrm{Si}_{136}$, were synthesized by thermal decomposition of $\mathrm{Na}_{4} \mathrm{Si}_{4}$ Zintl compound. ${ }^{1,2}$ The clathrate samples obtained by this method were powdery due to the solid state of the precursor compounds. Therefore, it is difficult to prepare the bulk crystal of the silicon clathrates containing Na. In our previous study, the single crystals of the Na-Si binary clathrate were successfully grown by using Sn flux. ${ }^{10,11}$ Single crystals of type-I $\mathrm{Na}_{8} \mathrm{Si}_{46}$ and type-II $\mathrm{Na}_{24} \mathrm{Si}_{136}$ clathrates were selectively grown in $\mathrm{Na}-\mathrm{Sn}$ rich Na-Sn-Si ternary melt by Na evaporation. ${ }^{11}$ Single crystals of a ternary type-I clathrate, $\mathrm{Na}_{8} \mathrm{Ga}_{5.70} \mathrm{Si}_{40.30}$, could also be prepared by a self-flux method using $\mathrm{Ga}$ as a flux. ${ }^{12}$ Furthermore, the crystal growth of $\mathrm{Na}_{8} \mathrm{Ga}_{x} \mathrm{Si}_{46-x}(x=4.94-5.52)$ clathrates was achieved by adding a Sn flux to the starting melt. We could measure the electrical resistivity of the single crystals for these clathrates containing Na. The clathrates exhibited metallic conduction, and their electrical resistivity decreased as the Ga content decreased (e.g., the resistivities of $\mathrm{Na}_{8} \mathrm{Ga}_{5.70} \mathrm{Si}_{40.30}$ and $\mathrm{Na}_{8} \mathrm{Ga}_{4.94} \mathrm{Si}_{41.06}$ were 1.40 and $0.72 \mathrm{~m} \Omega \mathrm{cm}$, respectively, at $300 \mathrm{~K}$ ).

To extend the variation of clathrate compounds and their field of properties and applications, doping or partial substitution of other atoms at the $\mathrm{Na}$ atom site is also designed. Recently, quaternary $\mathrm{Ga} / \mathrm{Si}$ and $\mathrm{Zn} / \mathrm{Si}$ clathrates having $\mathrm{Na}$ and $\mathrm{Rb}$ or Cs guest atoms, such as $\mathrm{Cs}_{6} \mathrm{Na}_{2} \mathrm{Ga}_{8.25} \mathrm{Si}_{37.75}, \mathrm{Rb}_{6.34^{-}}$ $\mathrm{Na}_{1.66} \mathrm{Ga}_{8.02} \mathrm{Si}_{37.98}$, and $\mathrm{Rb}_{8} \mathrm{Na}_{16} \mathrm{Zn}_{8.4} \mathrm{Si}_{127.6}$, have been synthesized using a Ga or Zn flux. ${ }^{13}$ However, the typical size of the single crystals was below $0.1 \mathrm{~mm}$, and the properties of the crystals could not be characterized. So, synthesis of quaternary $\mathrm{Na}$ and Si based clathrate single crystals with a size enough for 
characterization is still challenging. In the present study, we succeeded in growing the single crystals of quaternary $\mathrm{Ga}-\mathrm{Si}$ cage clathrate compounds encapsulating $\mathrm{Na}$ and $\mathrm{Sr}$ guest atoms by the Sn flux method. The compounds are the first examples of the $\mathrm{Ga} / \mathrm{Si}$ clathrates containing $\mathrm{Na}(1+)$ and other guest cations with a different formal ionic charge (2+). The crystal structures and electrical properties were investigated for the single crystals of the new clathrates.

\section{Experimental methods}

The experiments were conducted as described in the previous studies. ${ }^{10-12}$ Metal Na pieces (Nippon Soda Co. Ltd., 99.95\%), Si powder (Kojundo Chemical Laboratory Co. Ltd., 4N), Ga grains (Dowa Electronics Co. Ltd., 6N), and Sn granules (Mitsuwa Chemicals Co. Ltd., 5N) were combined by weight at a $\mathrm{Na}: \mathrm{Ga}: \mathrm{Si}: \mathrm{Sn}$ molar ratio of $6: 1: 2: 1$ (total $8.70 \mathrm{mmol}$ ) in a glove box with an Ar atmosphere. The raw material mixture was then put in a boron nitride (BN) crucible (Showa Denko KK; inner diameter of $6.5 \mathrm{~mm}$ and depth of $18 \mathrm{~mm}$ ) and sealed in a stainless steel (SUS) container (SUS316, outer diameter of $12.7 \mathrm{~mm}$, inner diameter of $10.7 \mathrm{~mm}$, and height of $80 \mathrm{~mm}$ ) with Ar gas. The SUS container was heated in an electric furnace at $1173 \mathrm{~K}$ for $12 \mathrm{~h}$ then the furnace was cooled to room temperature. The BN crucible was then taken from the SUS container in the glove box and Sr grains (Alfa Aeser, $4 \mathrm{~N}$ ) were added to the Na-Ga-Si-Sn mixture in the $\mathrm{BN}$ crucible to make the $\mathrm{Na}: \mathrm{Sr}: \mathrm{Ga}: \mathrm{Si}: \mathrm{Sn}$ molar ratio $6: 0.5: 1: 2: 1$. Next, the $B N$ crucible was sealed in the upper part of another long SUS container (outer diameter of 12.7 $\mathrm{mm}$, inner diameter of $10.7 \mathrm{~mm}$, and height of $300 \mathrm{~mm}$ ) with $\mathrm{Ar}$ gas. The upper part of the container was heated at $773 \mathrm{~K}$ for $12 \mathrm{~h}$, and the lower part was cooled using a fan to keep the temperature almost the same with the room temperature. By generating a temperature gradient in the container, the Na was evaporated from the mixture in the crucible, and condensed on the inner wall in the lower cooler part of the container.

After heating, the crucible was taken out in the glove box, and the weight loss from the sample was measured to calculate the amount of evaporated $\mathrm{Na}$ against the amount of $\mathrm{Na}$ in the starting mixture. The sample in the crucible was subjected to an alcohol treatment by which any excess $\mathrm{Na}$ and $\mathrm{Na}-\mathrm{Sn}$ and $\mathrm{Na}-$ Ga compounds in the sample were completely reacted with 2propanol followed by ethanol, and the reaction products of $\mathrm{Na}$ were removed from the samples by washing with water. A mixture of $\mathrm{Ga}$ and $\mathrm{Sn}$ remained after the decomposition of $\mathrm{Na}-$ $\mathrm{Sn}$ and Na-Ga compounds by the alcohol treatment and a $\mathrm{Sr}-$ Ga-Si ternary compound in the sample were then subjected to a hydrochloric acid treatment by dissolving in an aqueous hydrochloric acid (35.0-37.0 mass\% $\mathrm{HCl})$ and rinsing the residue with water.

The morphologies of the obtained single crystals were observed with an optical microscope (Olympus, SZX16) and a scanning electron microscope (SEM; JEOL, JXA-8200) at an accelerating voltage of $15 \mathrm{kV}$. The single crystals were cut to about $100-150 \mu \mathrm{m}$ in size and subjected to X-ray diffraction (XRD) measurements (Bruker, D8 QUEST). APEX3 ${ }^{14}$ was used to collect the diffraction data and refine the unit cells. X-ray absorption correction was performed by SADABS installed in APEX3 ${ }^{14}$ SHELEXL-97 software ${ }^{15}$ was used to refine the occupancies, coordinates, and displacement parameters of the atoms. The crystal structure was drawn by VESTA. ${ }^{16}$ The compositions of the obtained single crystals were analyzed with an electron-probe microanalyzer (EPMA, JEOL, JXA-8200). The electrical characteristics of the single crystals were measured in the range of $8-300 \mathrm{~K}$ by the four-terminal method using $\mathrm{Ag}$ paste as electrodes.

\section{Results and discussion}

When Sr was heated with other starting materials, at $1173 \mathrm{~K}$ for $12 \mathrm{~h}$, a SrGaSi ternary compound was crystallized. ${ }^{17}$ Once this compound was formed, it did not melt or dissolve into a liquid phase at $773 \mathrm{~K}$ and Sr was not provided to the crystal growth of clathrate. Thus, $\mathrm{Sr}$ was added to the $\mathrm{Na}-\mathrm{Ga}-\mathrm{Si}-\mathrm{Sn}$ mixture prepared in advance. By heating the Na-Ga-Si-Sn mixture and $\mathrm{Sr}$ at $773 \mathrm{~K}$ for $12 \mathrm{~h}, 46 \%$ of $\mathrm{Na}$ was evaporated. The residual excess $\mathrm{Na}$ and $\mathrm{Na}$ of $\mathrm{Na}-\mathrm{Sn}$ and $\mathrm{Na}-\mathrm{Ga}$ compounds in the sample were removed by the alcohol treatment. After hydrochloric acid treatment for removal of Sn and Ga by decomposition of the Na-Sn and Na-Ga compounds and a SrGaSi compound contained in the product, the black single crystals of
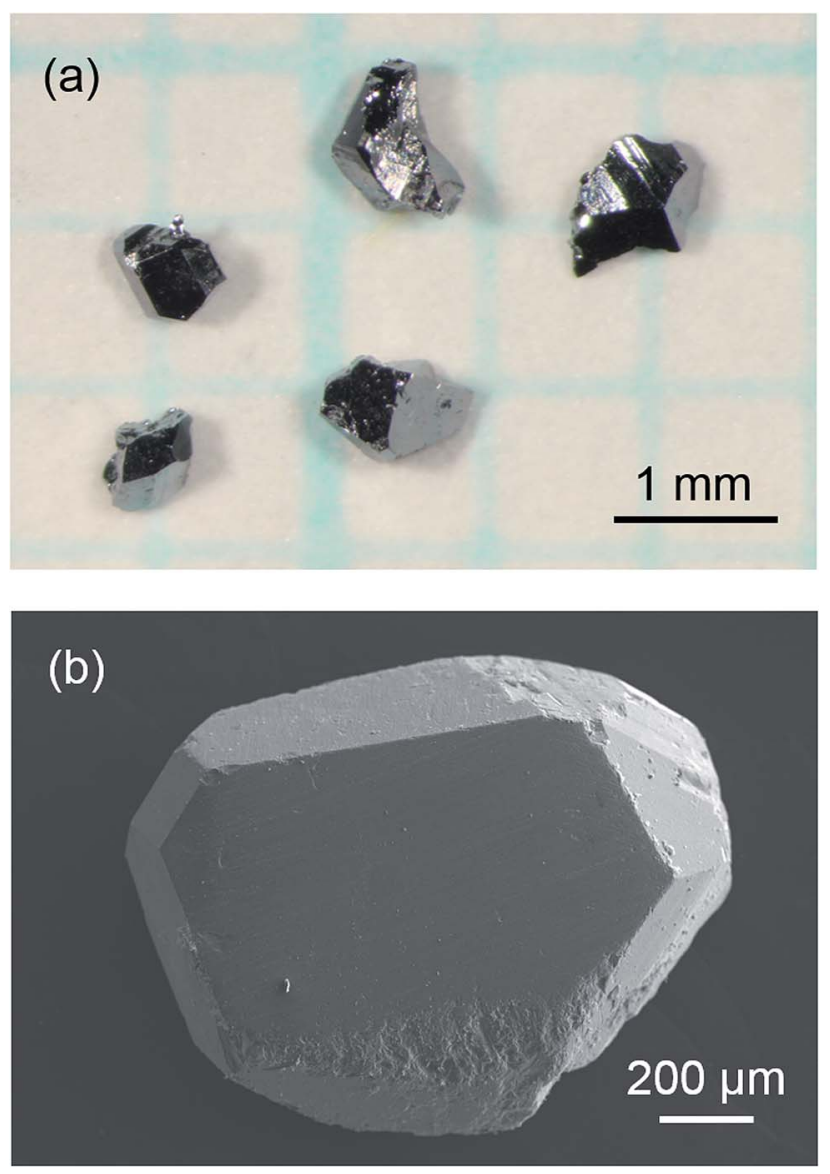

Fig. 1 Optical micrograph of the sample after the hydrochloric acid treatment (a) and an SEM image of a $\mathrm{Na}-\mathrm{Sr}-\mathrm{Ga}-\mathrm{Si}$ quaternary type-I clathrate single crystal (b). 
Table 1 Results of the EPMA analysis for crystals 1, 2, and 3

Composition (EPMA)

\begin{tabular}{|c|c|c|c|c|c|}
\hline Crystal & $\mathrm{Na}(\mathrm{at} \%)$ & $\mathrm{Sr}(\mathrm{at} \%)$ & $\mathrm{Ga}(\mathrm{at} \%)$ & $\mathrm{Si}(\mathrm{at} \%)$ & $\begin{array}{l}\text { Chemical formual } \\
(\mathrm{Ga}+\mathrm{Si}=46)\end{array}$ \\
\hline 1 & $9.08(44)$ & $6.06(33)$ & $14.01(45)$ & $70.85(31)$ & $\mathrm{Na}_{4.9(2)} \mathrm{Sr}_{3.3(2)} \mathrm{Ga}_{7.6(2)} \mathrm{Si}_{38.4(2)}$ \\
\hline 3 & $5.88(3)$ & $8.89(13)$ & $16.93(18)$ & $68.30(27)$ & $\mathrm{Na}_{3.2(1)} \mathrm{Sr}_{4.8(1)} \mathrm{Ga}_{9.1(1)} \mathrm{Si}_{36.9(2)}$ \\
\hline
\end{tabular}

clathrate were clearly separated. Fig. 1 shows optical and SEM micrographs of the crystals picked up from the obtained sample. Quantitative EPMA analyses were performed on the flat surfaces of the three black single crystals with sizes of $0.96 \mathrm{~mm}$ (crystal 1), $0.93 \mathrm{~mm}$ (crystal 2), and $0.83 \mathrm{~mm}$ (crystal 3) which were taken from the same sample. The $\mathrm{Na}, \mathrm{Sr}, \mathrm{Ga}$, and $\mathrm{Si}$ contents of crystals 1,2 , and 3 are summarized in Table 1 . The chemical formulas of crystals 1,2 , and 3 were calculated by setting the total number of $\mathrm{Si}$ and $\mathrm{Ga}$ atoms to 46 (based on the general formula of the type-I clathrate, $\left.\mathrm{Na}_{8-y} \mathrm{Sr}_{y} \mathrm{Ga}_{x} \mathrm{Si}_{46-x}\right)$ as $\mathrm{Na}_{4.9(2)} \mathrm{Sr}_{3.3(2)} \mathrm{Ga}_{7.6(2)} \mathrm{Si}_{38.4(2)}, \quad \mathrm{Na}_{3.8(5)} \mathrm{Sr}_{4.0(3)} \mathrm{Ga}_{8.4(2)} \mathrm{Si}_{37.3(2)}$, and $\mathrm{Na}_{3.2(1)} \mathrm{Sr}_{4.8(1)} \mathrm{Ga}_{9.1(1)} \mathrm{Si}_{36.9(2)}$, respectively. The sum of the $\mathrm{Na}$ and Sr numbers was close to 8. As shown in Fig. 2, the Sr content, $y$, linearly increased as the Ga content, $x$, increased. The largest crystal, crystal 1, had the smallest $\mathrm{Sr}$ and Ga contents among the three crystals.

In addition, cross sections of the crystals were also analyzed by EPMA; the results are shown in Fig. S1. $\dagger$ In crystals 2 and 3, $\mathrm{Na}, \mathrm{Sr}, \mathrm{Ga}$, and Si were homogeneously distributed. In contrast, in crystal 1, the surface was $\mathrm{Na}_{4.9(2)} \mathrm{Sr}_{3.3(2)} \mathrm{Ga}_{7.6(2)} \mathrm{Si}_{38.4(2)}$, but its composition changed sharply at one region that did not contain $\mathrm{Sr}$ and had a composition of $\mathrm{Na}_{8.3(2)} \mathrm{Ga}_{4.3(2)} \mathrm{Si}_{41.7(2)}$. The crystal 1 containing the $\mathrm{Na}-\mathrm{Ga}-\mathrm{Si}$ ternary clathrate part which were surrounded with the low $\mathrm{Sr}$ content $\mathrm{Na}_{4.9(2)} \mathrm{Sr}_{3.3(2)} \mathrm{Ga}_{7.6(2)} \mathrm{Si}_{38.4(2)}$ was probably grown at the early stage of the crystal formation. This may indicate that $\mathrm{Sr}$ which was added to the $\mathrm{Na}-\mathrm{Ga}-\mathrm{Si}-\mathrm{Sn}$ mixture was gradually provided to the melt during heating at

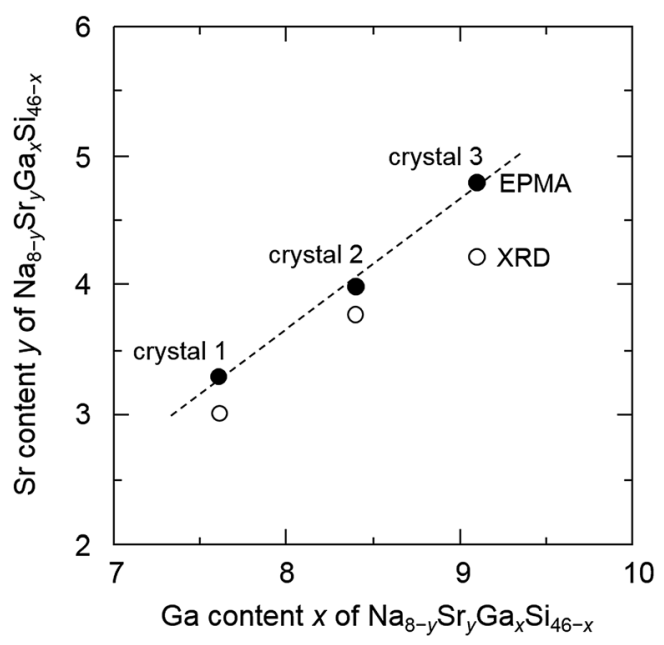

Fig. 2 Sr content (y) versus Ga content (x) of $\mathrm{Na}_{8-y} \mathrm{Sr}_{y} \mathrm{Ga}_{x} \mathrm{Si}_{46-x}$.
$773 \mathrm{~K}$. Homogeneous and high Sr concentrations in the crystals 2 and 3 suggest the crystal growth from Sr-rich melts at later stages. Further studies are needed to clarify the process by which crystals with different $\mathrm{Sr}$ and $\mathrm{Ga}$ contents are grown from the same starting mixture.

The results of the X-ray crystal structure analyses of pieces from the surface of crystals 1-3 are listed in Tables 2-4. The crystal structures were analyzed based on the model of a type-I clathrate (space group, $P m \overline{3} n$ ). The occupancies of Si/Ga1(24k), $\mathrm{Si} / \mathrm{Ga} 2(16 \mathrm{i})$, and $\mathrm{Si} / \mathrm{Ga} 3(6 \mathrm{c})$ were refined under the constraint that the total Ga content was equal to that measured by EPMA. The reliability factor, $R 1$ (all), was in the range of $1.13-1.34 \%$ for all analyses. The chemical formulas of crystals 1,2 , and 3 were calculated from the refined occupancies as $\mathrm{Na}_{5.04} \mathrm{Sr}_{2.96(2)} \mathrm{Ga}_{7.6^{-}}$ $\mathrm{Si}_{38.4}, \quad \mathrm{Na}_{4.20} \mathrm{Sr}_{3.80(3)} \mathrm{Ga}_{8.4} \mathrm{Si}_{37.6}$, and $\mathrm{Na}_{3.92} \mathrm{Sr}_{4.08(2)} \mathrm{Ga}_{9.1} \mathrm{Si}_{36.9}$, respectively. The $\mathrm{Sr}$ contents were relatively consistent with those derived by EPMA (3.3(2), 4.0(3), 4.8(1)). The unit cell constants increased with the increase of the Ga and Sr contents (10.3645(3), 10.3747(3), and 10.3804(4) A for crystals 1, 2, and 3, respectively).

The pentagonal dodecahedral $\left([\mathrm{Si} / \mathrm{Ga}]_{20}\right)$ and tetrakaidecahedral ([Si/Ga $]_{24}$ ) cages of $\mathrm{Na}_{3.92} \mathrm{Sr}_{4.08(2)} \mathrm{Ga}_{9.1} \mathrm{Si}_{36.9}$ (crystal 3) are depicted in Fig. 3. In crystals 1, 2, and 3, the Ga occupancies for the $\mathrm{Si} / \mathrm{Ga} 1(24 \mathrm{k}), \mathrm{Si} / \mathrm{Ga} 2(16 \mathrm{i})$, and $\mathrm{Si} / \mathrm{Ga} 3(6 \mathrm{c})$ sites ranged from 0.1005 (7) to $0.1387(8), 0.0344(10)$ to $0.0613(11)$, and $0.773(2)$ to $0.798(2)$, respectively, and $\mathrm{Ga}$ atoms preferentially occupied the $\mathrm{Si} / \mathrm{Ga} 3(6 \mathrm{c})$ sites in the $[\mathrm{Si} / \mathrm{Ga}]_{24}$ cages. Similar preferential occupation of $\mathrm{Ga}$ atoms in the $\mathrm{Si} / \mathrm{Ga} 3(6 \mathrm{c})$ sites has been previously reported for other type-I clathrates, $\mathrm{Rb}_{6.34} \mathrm{Na}_{1.66(2)} \mathrm{Ga}_{8.02}{ }^{-}$ $\mathrm{Si}_{37.98(3)}$ and $\mathrm{Cs}_{6} \mathrm{Na}_{2} \mathrm{Ga}_{8.25} \mathrm{Si}_{37.75(3)} \cdot{ }^{13}$ The occupancies of the $\mathrm{Sr}$ atoms for the $\mathrm{Na} / \mathrm{Sr} 2(2 \mathrm{a})$ sites in the $[\mathrm{Si} / \mathrm{Ga}]_{20}$ cages $(0.605(3)-$ $0.734(3))$ were larger than those for the $\mathrm{Na} / \mathrm{Sr} 1(6 \mathrm{~d})$ sites in the $[\mathrm{Si} / \mathrm{Ga}]_{24}$ cages $(0.291(3)-0.435(3))$. Further, the volumes of the $[\mathrm{Si} / \mathrm{Ga}]_{20}$ cages $\left(107.2-107.8 \AA^{3}\right)$ were smaller than those of the $[\mathrm{Si} / \mathrm{Ga}]_{24}$ cages $\left(142.8-143.4 \AA^{3}\right)$. In the $\mathrm{Cs}_{6} \mathrm{Na}_{2} \mathrm{Ga}_{8.25} \mathrm{Si}_{37.75}$ and $\mathrm{Rb}_{6.34} \mathrm{Na}_{1.66} \mathrm{Ga}_{8.02} \mathrm{Si}_{37.98}$ crystals, Cs and $\mathrm{Rb}$ fully occupy the $6 \mathrm{~d}$ sites inside the larger cage of $[\mathrm{Si} / \mathrm{Ga}]_{24}$, which indicates selective occupation of larger cations in larger cages. ${ }^{13}$ In the present study, Sr atom preferred to occupy the 2a sites in the smaller [Si/ $\mathrm{Ga}_{20}$ cage despite the atomic size of $\mathrm{Sr}$ larger than that of $\mathrm{Na}$. This result suggests that the cation size is not related to the site preference in the $\mathrm{Na}_{8-y} \mathrm{Sr}_{y} \mathrm{Ga}_{x} \mathrm{Si}_{46-x}$ clathrate. Since the electronegativities (Pauling scale $\left.{ }^{18}\right)$ of $\mathrm{Rb}\left(\chi_{\mathrm{P}}^{\mathrm{Rb}}=0.82\right)$ and $\mathrm{Cs}\left(\chi_{\mathrm{P}}^{\mathrm{Cs}}=\right.$ 0.79) in the $\mathrm{Cs}_{6} \mathrm{Na}_{2} \mathrm{Ga}_{8.25} \mathrm{Si}_{37.75}$ and $\mathrm{Rb}_{6.34} \mathrm{Na}_{1.66} \mathrm{Ga}_{8.02} \mathrm{Si}_{37.98}$ were smaller than that of $\mathrm{Na}\left(\chi_{\mathrm{P}}^{\mathrm{Na}}=0.93\right)$, the outermost electrons of $\mathrm{Rb}$ and $\mathrm{Cs}$ atoms could effectively be transferred to the 
Table 2 Crystal data, data collection, and refinement for the XRD analysis of $\mathrm{Na}-\mathrm{Sr}-\mathrm{Ga}-\mathrm{Si}$ quaternary single crystals ${ }^{a}$

\begin{tabular}{|c|c|c|c|}
\hline & Crystal 1 & Crystal 2 & Crystal 3 \\
\hline Chemical formula & $\mathrm{Na}_{5.04} \mathrm{Sr}_{2.96(2)} \mathrm{Ga}_{7.6} \mathrm{Si}_{38.4}$ & $\mathrm{Na}_{4.20} \mathrm{Sr}_{3.80(3)} \mathrm{Ga}_{8.4} \mathrm{Si}_{37.6}$ & $\mathrm{Na}_{3.92} \mathrm{Sr}_{4.08(2)} \mathrm{Ga}_{9.1} \mathrm{Si}_{36.9}$ \\
\hline Formula weight, $M_{\mathrm{r}}\left(\mathrm{g} \mathrm{mol}{ }^{-1}\right), Z$ & $1983.75,1$ & $2071.35,1$ & $2118.58,1$ \\
\hline Crystal system, space group & Cubic, $P m \overline{3} n$ & Cubic, $P m \overline{3} n$ & Cubic, $P m \overline{3} n$ \\
\hline Unit-cell dimension, $a(\AA)$ & $10.3645(3)$ & $10.3747(3)$ & $10.3804(4)$ \\
\hline Unit-cell volume, $V\left(\AA^{3}\right)$ & $1113.38(10)$ & $1116.67(10)$ & $1118.52(13)$ \\
\hline Size $\left(\mathrm{mm}^{3}\right)$ & $0.216 \times 0.160 \times 0.152$ & $0.141 \times 0.174 \times 0.183$ & $0.142 \times 0.152 \times 0.149$ \\
\hline Absorption correction & Multi-scan & Multi-scan & Multi-scan \\
\hline absorption coefficient, $\mu\left(\mathrm{mm}^{-1}\right)$ & 9.139 & 10.544 & 11.248 \\
\hline \multirow[t]{3}{*}{ Limiting indices } & $-11 \leq h \leq 14$ & $-10 \leq h \leq 14$ & $-13 \leq h \leq 9$ \\
\hline & $-10 \leq k \leq 13$ & $-12 \leq k \leq 12$ & $-10 \leq k \leq 14$ \\
\hline & $-12 \leq l \leq 10$ & $-14 \leq l \leq 11$ & $-11 \leq l \leq 13$ \\
\hline Date/restraints/parameters & $284 / 1 / 21$ & $284 / 1 / 21$ & $284 / 1 / 21$ \\
\hline Weight parameters, $a, b$ & $0.0101,0.2875$ & $0.0129,0.2629$ & $0.0101,0.2209$ \\
\hline Goodness-of-fit on $F^{2}, S$ & $1.223,1.220$ & $1.191,1.189$ & $1.223,1.220$ \\
\hline$R_{1}, \mathrm{w} R_{2}(I>2 \sigma(I))$ & $0.0113,0.0254$ & $0.0113,0.0283$ & $0.0134,0.0311$ \\
\hline$R_{1}, \mathrm{w} R_{2}$ (all date) & $0.0124,0.0258$ & $0.0125,0.0287$ & $0.0143,0.0314$ \\
\hline Largest diff. park and hole, $\Delta \rho\left(\mathrm{e}^{-3}\right)$ & $0.326,-0.242$ & $0.261,-0.239$ & $0.329,-0.244$ \\
\hline
\end{tabular}

${ }^{a} R_{1}=\Sigma|| F_{\mathrm{o}}|-| F_{\mathrm{c}}|| / \Sigma\left|F_{\mathrm{o}}\right| . \mathrm{w} R_{2}=\left[\Sigma \mathrm{w}\left(F_{\mathrm{o}}{ }^{2}-F_{\mathrm{c}}{ }^{2}\right)^{2} / \Sigma\left(\mathrm{w} F_{\mathrm{o}}{ }^{2}\right)^{2}\right]^{1 / 2}, \mathrm{w}=1 /\left[\sigma^{2}\left(F_{\mathrm{o}}{ }^{2}\right)+(a P)^{2}+b P\right]$, where $F_{\mathrm{o}}$ is the observed structure factor, $F_{\mathrm{c}}$ is the calculated structure factor, $\sigma$ is the standard deviation of $F_{\mathrm{c}}{ }^{2}$, and $P=\left(F_{\mathrm{o}}{ }^{2}+2 F_{\mathrm{c}}{ }^{2}\right) / 3 . S=\left[\Sigma \mathrm{w}\left(F_{\mathrm{o}}{ }^{2}-F_{\mathrm{c}}{ }^{2}\right)^{2} /(n-p)\right]^{1 / 2}$, where $n$ is the number of reflections and $p$ is the total number of parameters refined.

more electronegative $\mathrm{Ga}$ atoms $\left(\chi_{\mathrm{P}}^{\mathrm{Ga}}=1.81\right)$. In the case of $\mathrm{Na}_{8-y} \mathrm{Sr}_{y} \mathrm{Ga}_{x} \mathrm{Si}_{46-x}$, the electronegativities of $\mathrm{Sr}\left(\chi_{\mathrm{P}}^{\mathrm{Sr}}=0.95\right)$ and $\mathrm{Na}\left(\chi_{\mathrm{P}}^{\mathrm{Na}}=0.93\right)$ were similar, but the first ionization energy of $\mathrm{Na}(5.139 \mathrm{eV})$ was smaller than that of $\mathrm{Sr}(5.695 \mathrm{eV}) .{ }^{19}$ Thus, Na atoms may preferentially occupy the Ga-rich $[\mathrm{Si} / \mathrm{Ga}]_{24}$ cages of $\mathrm{Na}_{8-y} \mathrm{Sr}_{y} \mathrm{Ga}_{x} \mathrm{Si}_{46-x}$ clathrates.
The crystal structure of $\mathrm{Na}_{3.92} \mathrm{Sr}_{4.08(2)} \mathrm{Ga}_{9.1} \mathrm{Si}_{36.9}$ (crystal 3) is drawn with displacement ellipsoids representing the $99 \%$ probability region in Fig. S2. $\dagger$ The $U_{22}=U_{33}$ parameters of the $\mathrm{Na} / \mathrm{Sr} 1(6 \mathrm{~d})$ sites in crystals 1,2 , and 3 were $0.0508(4), 0.0524(5)$, and $0.0512(5) \AA^{2}$, respectively, which were larger than the atomic displacement parameters of $U_{11}(0.0272(5), 0.0244(5)$,

Table 3 Atomic coordinates and equivalent isotropic displacement parameters $\left(U_{\text {eq }} / \AA^{2}\right)$ of crystals 1,2 , and 3

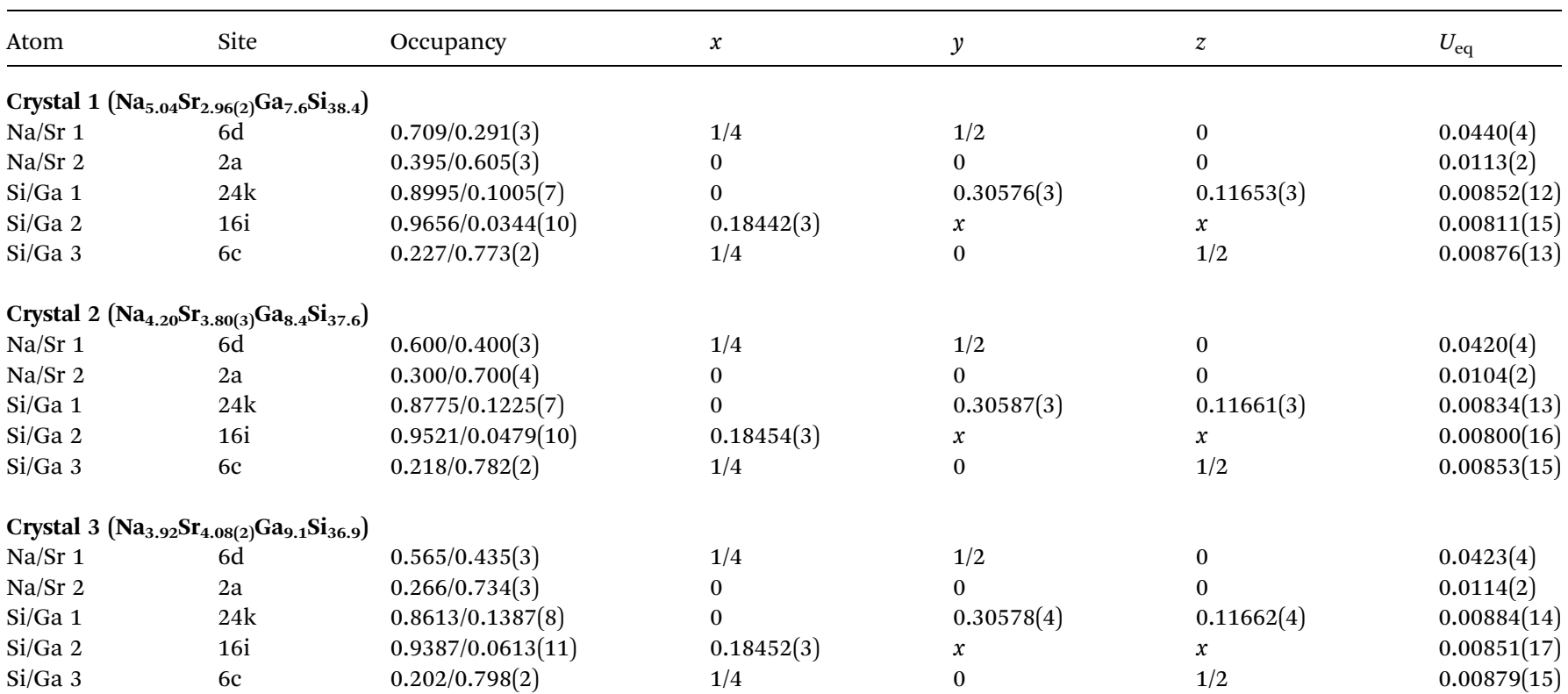


Table 4 Anisotropic displacement parameters $\left(U_{i j} / \AA^{2}\right)$ for crystals 1,2 , and 3

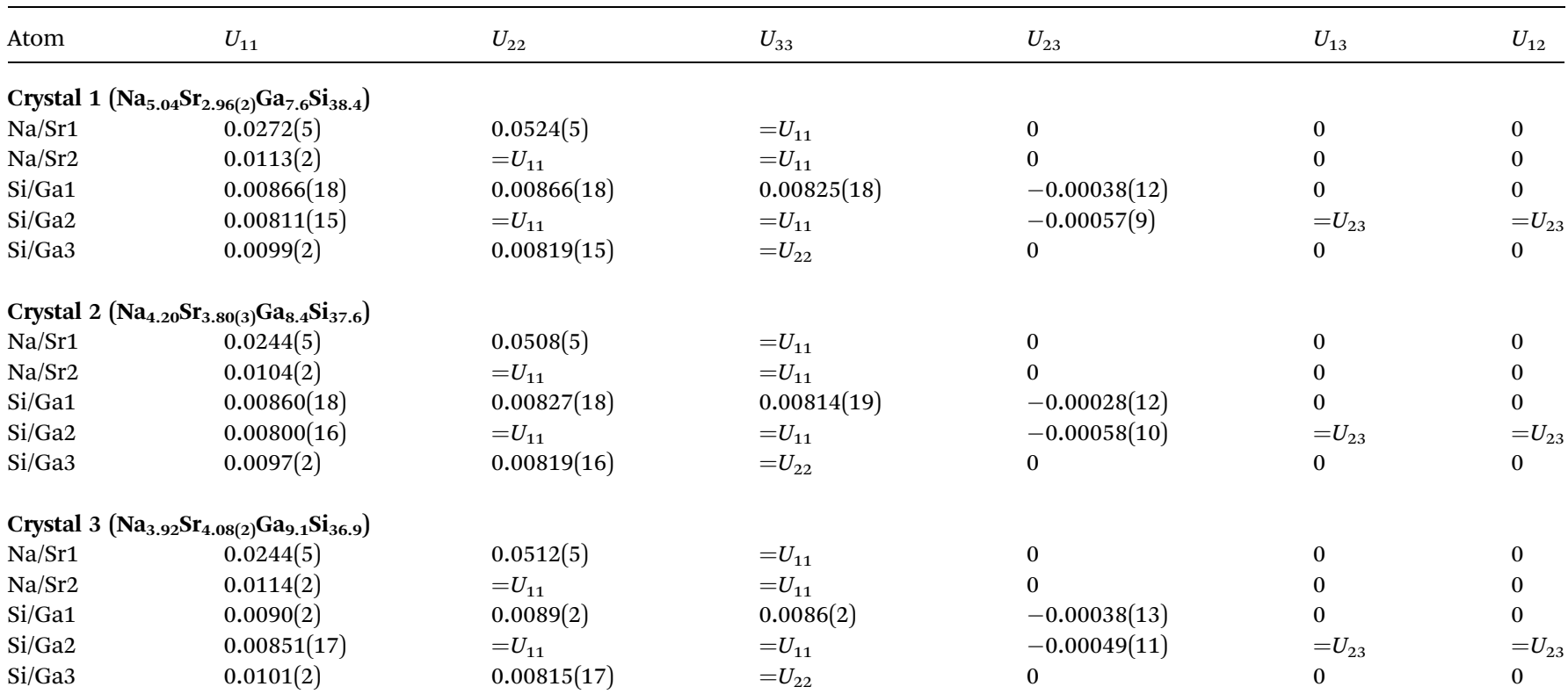

and 0.0244(5) $\left.\AA^{2}\right)$ and much larger than those of $U_{i j}$ at other sites $\left(\leq 0.0114(2) \AA^{2}\right)$ (Table 4). This probably corresponds to the large, distorted shape of the $[\mathrm{Si} / \mathrm{Ga}]_{24}$ cages. Such large anisotropic atomic displacement parameters of $U_{22}=U_{33}$ for the $6 \mathrm{~d}$ sites in $[\mathrm{Si} / \mathrm{Ga}]_{24}$ cages have similarly been reported for other type-I clathrates including $\mathrm{Na}_{8} \mathrm{Ga}_{x} \mathrm{Si}_{46-x}(4.94(6) \leq x \leq$ 5.70(7)), ${ }^{12} \mathrm{~A}_{8} \mathrm{Ga}_{8} \mathrm{Si}_{38}$ (A = K, Rb, Cs), ${ }^{5} \mathrm{Rb}_{6.34} \mathrm{Na}_{1.66(2)} \mathrm{Ga}_{8.02}$ $\mathrm{Si}_{37.98(3)}$, and $\mathrm{Cs}_{6} \mathrm{Na}_{2} \mathrm{Ga}_{8.25} \mathrm{Si}_{37.75(3)} \cdot{ }^{13}$

Fig. 4 shows the temperature dependence of electrical resistivity, $\rho$, measured for the three crystals and the type-I clathrate single crystal, $\mathrm{Na}_{8} \mathrm{Ga}_{5.7} \mathrm{Si}_{40.3}$, synthesized by our group in a previous study. ${ }^{12}$ The $\rho$ values for crystals 1,2 , and 3 increased with increasing temperature, reaching $0.34,0.55$, and $1.05 \mathrm{~m} \Omega \mathrm{cm}$, respectively, at room temperature $(300 \mathrm{~K})$. The previously reported electrical resistivities at $280-300 \mathrm{~K}$ for other type-I clathrates, $\mathrm{Na}_{8} \mathrm{Si}_{46},{ }^{20} \mathrm{Na}_{8} \mathrm{Ga}_{x} \mathrm{Si}_{46-x},{ }^{12}$ and $\mathrm{Sr}_{8} \mathrm{Ga}_{x} \mathrm{Si}_{46-x},{ }^{8,9}$ are compared to those in the $\mathrm{Na}_{8-y} \mathrm{Sr}_{y} \mathrm{Ga}_{x} \mathrm{Si}_{46-x}$ sample (crystal 1: $\mathrm{Na}_{5.0} \mathrm{Sr}_{3.0} \mathrm{Ga}_{7.6} \mathrm{Si}_{38.4}$, crystal 2: $\mathrm{Na}_{4.2} \mathrm{Sr}_{3.8} \mathrm{Ga}_{8.4} \mathrm{Si}_{37.6}$, and crystal

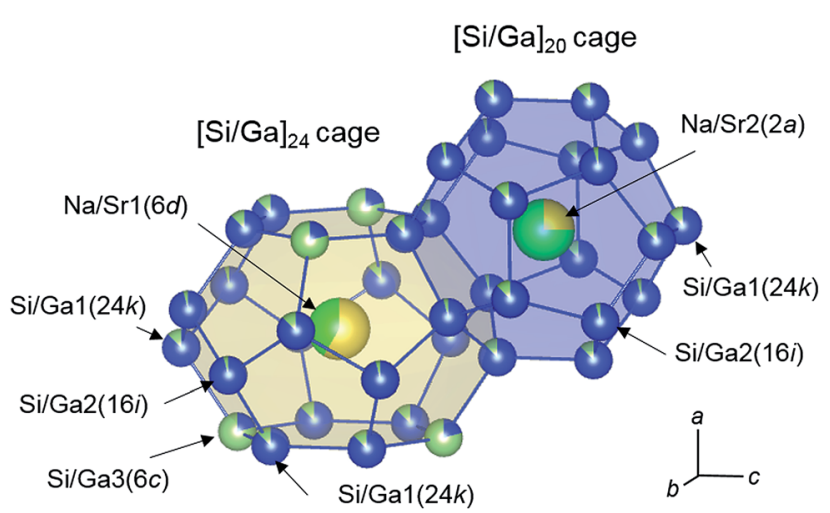

Fig. 3 Structures of the $[\mathrm{Si} / \mathrm{Ga}]_{20}$ and $[\mathrm{Si} / \mathrm{Ga}]_{24}$ cages of $\mathrm{Na}_{3.9} \mathrm{Sr}_{4.1^{-}}$ $\mathrm{Ga}_{9.1} \mathrm{Si}_{36.9}$ ( $\mathrm{Na}$ : yellow, Ga: yellow-green, $\mathrm{Si}$ : blue, Sr: green). The occupancies are represented by the surface areas of the spheres.
3: $\left.\mathrm{Na}_{3.9} \mathrm{Sr}_{4.1} \mathrm{Ga}_{9.1} \mathrm{Si}_{36.9}\right)$ with respect to their respective $\mathrm{Ga}$ contents, $x$, in Fig. 5 . The electrical resistivity of crystal 1 was plotted at $x=7.6$ in Fig. 5 even though one region in the $\mathrm{Na}_{4.9(2)} \mathrm{Sr}_{3.3(2)} \mathrm{Ga}_{7.6(2)} \mathrm{Si}_{38.4(2)}$ crystal had a composition of $\mathrm{Na}_{8.3(2)} \mathrm{Ga}_{4.3(2)} \mathrm{Si}_{41.7(2)}$ (as shown in Fig. S1†).

The resistivity of $\mathrm{Na}_{8} \mathrm{Ga}_{x} \mathrm{Si}_{46-x}$ was greater than that of $\mathrm{Na}_{8} \mathrm{Si}_{46}(0.098 \mathrm{~m} \Omega \mathrm{cm})$ as measured previously by Stefanoski at $300 \mathrm{~K}^{20}$ and increased with increasing $x .{ }^{12}$ Eight electrons are formally transferred from $\mathrm{Na}$ to the $\mathrm{Si}$ framework to form $\mathrm{Na}_{8} \mathrm{Si}_{46}$; these electrons enter into the conduction band. Since the valences of $\mathrm{Si}$ and $\mathrm{Ga}$ are 4 and 3, respectively, the number

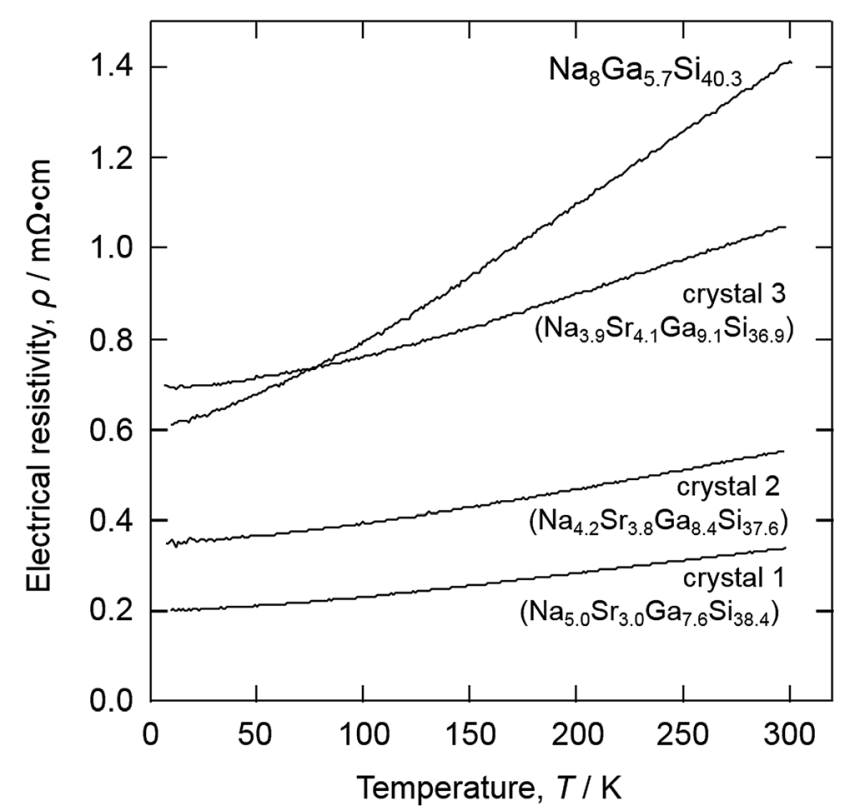

Fig. 4 Temperature dependence of the electrical resistivity of crystal 1 $\left(\mathrm{Na}_{5.0} \mathrm{Sr}_{3.0} \mathrm{Ga}_{7.6} \mathrm{Si}_{38.4}\right)$, crystal $2\left(\mathrm{Na}_{4.2} \mathrm{Sr}_{3.8} \mathrm{Ga}_{8.4} \mathrm{Si}_{37.6}\right)$, crystal $3\left(\mathrm{Na}_{3.9^{-}}\right.$ $\left.\mathrm{Sr}_{4.1} \mathrm{Ga}_{9.1} \mathrm{Si}_{36.9}\right)$, and $\mathrm{Na}_{8} \mathrm{Ga}_{5.7} \mathrm{Si}_{40.3 .}{ }^{12}$ 


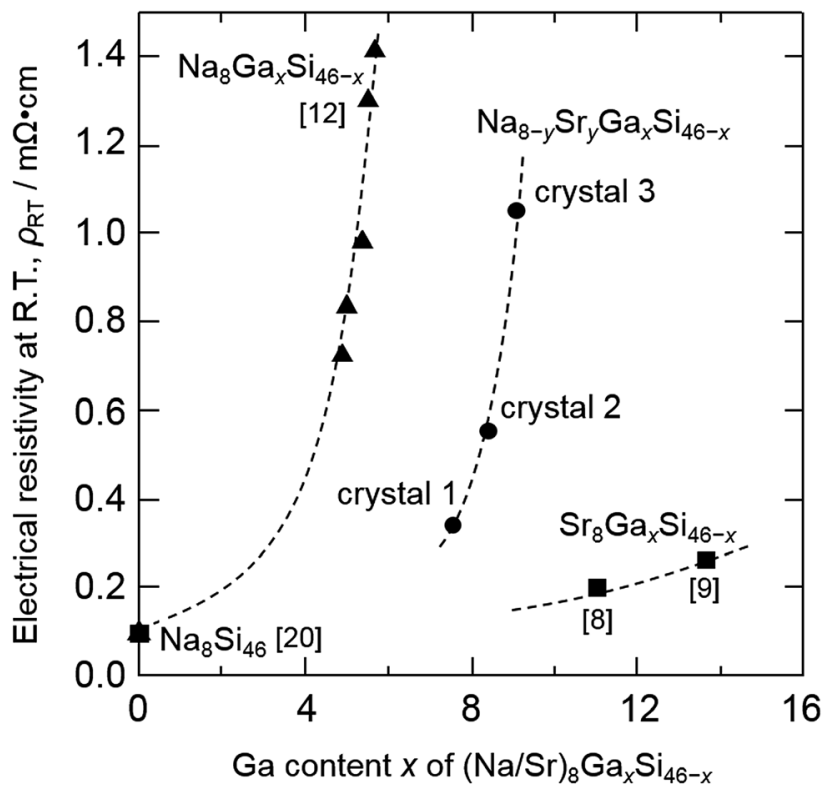

Fig. 5 Electrical resistivity at room temperature versus Ga content of type-I clathrates: $\mathrm{Na}_{8} \mathrm{Si}_{46},{ }^{20} \quad \mathrm{Na}_{8} \mathrm{Ga}_{x} \mathrm{Si}_{46-x},{ }^{12} \quad \mathrm{Sr}_{8} \mathrm{Ga}_{x} \mathrm{Si}_{46-x},{ }^{8,9}$ and $\mathrm{Na}_{8-y} \mathrm{Sr}_{y} \mathrm{Ga}_{x} \mathrm{Si}_{46-x}$ crystals $1\left(\mathrm{Na}_{5.0} \mathrm{Sr}_{3.0} \mathrm{Ga}_{7.6} \mathrm{Si}_{38.4}\right), 2\left(\mathrm{Na}_{4.2} \mathrm{Sr}_{3.8} \mathrm{Ga}_{8.4^{-}}\right.$ $\left.\mathrm{Si}_{37.6}\right)$, and $3\left(\mathrm{Na}_{3.9} \mathrm{Sr}_{4.1} \mathrm{Ga}_{9.1} \mathrm{Si}_{36.9}\right)$.

of the electrons (or carriers) in the conduction band should decrease with increasing Ga content in the [Si/Ga] framework, thus reducing the conductivities and changing the structure to a semiconducting Zintl clathrate with $x=8$ like $\mathrm{A}_{8} \mathrm{Ga}_{8} \mathrm{Si}_{38}$ (A = $\mathrm{K}, \mathrm{Rb}, \mathrm{Cs}) .{ }^{5}$ The $\rho$ values of $\mathrm{Na}_{8-y} \mathrm{Sr}_{y} \mathrm{Ga}_{x} \mathrm{Si}_{46-x}$ and $\mathrm{Sr}_{8} \mathrm{Ga}_{x} \mathrm{Si}_{46-x}$ followed trends similar to that shown in Fig. 5. $\mathrm{Na}_{5.04} \mathrm{Sr}_{2.96(2)^{-}}$ $\mathrm{Ga}_{7.6} \mathrm{Si}_{38.4}$ (crystal 1), $\mathrm{Na}_{4.20} \mathrm{Sr}_{3.80(3)} \mathrm{Ga}_{8.4} \mathrm{Si}_{37.6}$ (crystal 2), and $\mathrm{Na}_{3.92} \mathrm{Sr}_{4.08(2)} \mathrm{Ga}_{9.1} \mathrm{Si}_{36.9}$ (crystal 3) have valence electron numbers of $3.36,3.40$, and 2.98 , respectively, and crystal 3 exhibited the highest resistivity among $\mathrm{Na}_{8-y} \mathrm{Sr}_{y} \mathrm{Ga}_{x} \mathrm{Si}_{46-x}$. The resistivity of crystal 2 is higher than crystal 1 although the numbers are almost the same. The resistivity may also be related to the content of $\mathrm{Ga}$ atoms which scatter conduction carrier electrons and holes on the clathrate frame. The Ga content of crystal $2(x=8.40)$ is higher than crystal $1(x=7.6)$.

\section{Summary}

Here, single crystals of quaternary type-I clathrates, $\mathrm{Na}_{8-y} \mathrm{Sr}_{y^{-}}$ $\mathrm{Ga}_{x} \mathrm{Si}_{46-x}$, were grown by heating a Na-Sr-Ga-Si melt at $773 \mathrm{~K}$ and evaporating the $\mathrm{Na}$ from the melt in an $\mathrm{Ar}$ atmosphere. The compositions and crystal structures of the single crystals were analyzed by EPMA and XRD. The Ga and Sr contents ( $x$ and $y$ ) of the obtained crystals were 7.6-9.1 and 2.96(2)-4.08(2), respectively. $\mathrm{Na}$ atoms preferentially occupied the $\mathrm{Na} / \mathrm{Si} 1(6 \mathrm{~d})$ sites, whereas $\mathrm{Ga}$ atoms preferentially occupied the $\mathrm{Si} / \mathrm{Ga} 3(6 \mathrm{c})$ sites in the $[\mathrm{Si} / \mathrm{Ga}]_{24}$ cages. The electrical resistivities of the
$\mathrm{Na}_{8-y} \mathrm{Sr}_{y} \mathrm{Ga}_{x} \mathrm{Si}_{46-x}$ single crystals were found to increase from 0.34 to $1.05 \mathrm{~m} \Omega \mathrm{cm}$ with increasing $x$ and $y$ at $300 \mathrm{~K}$.

\section{Conflicts of interest}

There are no conflicts to declare.

\section{Acknowledgements}

The authors would like to thank T. Kamaya for the EPMA analysis. This work was supported by JSPS KAKENHI grants (JP16H06123 and JP18H01887).

\section{References}

1 J. S. Kasper, P. Hagenmuller, M. Pouchard and C. Cros, Science, 1965, 150, 1713.

2 C. Cros and M. Pouchard, C. R. Chim., 2009, 12, 1014.

3 H. Kawaji, H. Horie, S. Yamanaka and M. Ishikawa, Phys. Rev. B: Condens. Matter Mater. Phys., 1994, 74, 8.

4 S. Yamanaka, E. Enishi, H. Fukuoka and M. Yasukawa, Inorg. Chem., 2000, 39, 56.

5 F. Sui, H. He, S. Bobev, J. Zhao, F. E. Osterloh and S. M. Kauzlarich, Chem. Mater., 2015, 27, 2812.

6 J. L. Cohn, G. S. Nolas, V. Fessatidis, T. H. Metcalf and G. A. Slack, Phys. Rev. Lett., 1999, 82, 779.

7 V. L. Kuznetsov, L. A. Kuznetsova, A. E. Kaliazin and D. M. Rowe, J. Appl. Phys., 2000, 87, 7871.

8 M. Imai, K. Nishida, T. Kimura and K. Yamada, J. Alloys Compd., 2002, 335, 270.

9 K. Suekuni, M. A. Avila, K. Umeo and T. Takabatake, Phys. Rev. B: Condens. Matter Mater. Phys., 2007, 75, 195210.

10 H. Morito, M. Shimoda and H. Yamane, J. Cryst. Growth, 2016, 450, 164.

11 H. Morito, M. Shimoda, H. Yamane and K. Fujiwara, Cryst. Growth Des., 2018, 18, 351.

12 H. Urushiyama, M. Morito, H. Yamane and M. Terauchi, RSC $A d v ., 2018$, 8, 40505.

13 M. C. Schäfer and S. Bobev, Inorganics, 2014, 2, 79.

14 Bruker AXS, Instrument Service v6.2.3, APEX3 v2016.9-0, $S A D A B S, \quad S A I N T$ v8.37A, XT v2014/5, Bruker AXS Inc., Madison, Wisconsin, USA, 2014.

15 G. M. Sheldrick, Acta Crystallogr., 2015, C71, 3.

16 K. Momma and F. Izumi, J. Appl. Crystallogr., 2011, 44, 1272.

17 R. L. Meng, B. Lorenz, Y. S. Wang, J. Cmaidalka, Y. Y. Sun, Y. Y. Xue, J. K. Meen and C. W. Chu, Physica C, 2002, 382, 113.

18 L. Pauling, Nature of the Chemical Bond, Cornell University Press, 1960, pp. 88-107.

19 CRC Handbook Chemistry and Physics, ed. W. M. Haynes, CRC Press, 97th edn, 2016-2017, pp. 10-204.

20 S. Stefanoski, J. Martin and G. S. Nolas, J. Phys.: Condens. Matter, 2010, 22, 485404. 